九州大学学術情報リポジトリ

Kyushu University Institutional Repository

\title{
Developmental Changes in RNA Synthesis in Nuclei Isolated from the Midgut of Bombyx mori
}

Kami jo, Se i ji

Laboratory of Sericulture, Faculty of Agriculture, Kyushu University

Fujii, Hiroshi

Laboratory of Sericulture, Faculty of Agriculture, Kyushu University

Hayashi, Katsuya

Laboratory of Sericultural Chemistry, Faculty of Agriculture, Kyushu University

Sakaguchi, Bungo

Laboratory of Sericulture, Faculty of Agriculture, Kyushu University

https://doi.org/10.5109/23658

出版情報：九州大学大学院農学研究院紀要. 22 (3)，pp. 125-132，1978-07. Kyushu University バージョン：

権利関係 : 


\title{
Developmental Changes in RNA Synthesis in Nuclei Isolated from the Midgut of Bombyx mori
}

\author{
Seiji Kamijo, Hiroshi Fujii, Katsuya Hayashi* \\ and Bungo Sakaguchi \\ Laboratory of Sericulture and *Laboratory of Sericultural Chemistry, \\ Faculty of Agriculture, Kyushu University 46-01, Fukuoka 812
}

(Received October 11, 1977)

\begin{abstract}
The rate of RNA synthesis in the midgut of Bombyx mori during the period of larvalpupal development was assayed in vitro with isolated nuclei. The synthesis was examined with or without ecdysterone added in the assay medium, and the products were analyzed by means of polyacrylamide gel electrophoresis. The rate of RNA synthesis in nuclei isolated at the gluttonous stage (day 3 of the 5 th instar) was 2.5 times as high as that in nuclei from the mature larvae (day 7 of the 5 th instar), and the RNA species synthesized in the two preparations of nuclei were different. Both syntheses were stimulated by ecdysterone added in the reaction mixture, but features of the hormonal effect were different between the two larval stages. In case of the gluttonous stage, new species of RNA were found to be synthesized in ecdysteronetreated nuclei. On the other hand, nuclei from the mature larvae showed only quantitative hut not qualitative stimulation by the hormone. Many of the ecdysterone-stimulated RNA species found in midgut cell nuclei from the gluttonous larvae were similar to those found in nuclei from the mature larvae.
\end{abstract}

\section{INTRODUCTION}

The midgut of the silkworm, Bombyx mori, changes structurally and functionally during larval-pupal metamorphosis. At the first half of the 5 th instar when the larvae are voracious, the organ plays a major role in the digestive process, exhibiting a tight assembly of the columnar and goblet cells, which bear digestive and absorptive functions, respectively. After the onset of larval maturation which is triggered by ecdysone, the midgut decreases in volume, and the constituent cells are gradually degraded and replaced by generative cells multiplying to form a new midgut charateristic of the pupal stage (Kawaguchi, 1931; Machida, 1933; Tsujita, 1943). The function of the latter organ has not exactly been clarified but it may play some role in secreting the cocoon digesting enzyme (Eguchi et al., 1975). These structural and functional changes of the midgut during development may possibly be affected by transcriptional processes, since there has been observed a difference in activity of RNA synthesis in the nuclear fraction of midgut between the feeding and maturation stages (Fujii and Sakaguchi, 1971). In the present study, we have isolated nuclei from the midgut of both the gluttonous and mature larvae, and compared the RNA species synthesized in vitro. The nuclei were incubated with or without ecdysterone added to the medium in order to examine the 
hormonal effects on nuclear events.

\section{MATERIALS AND METHODS}

\section{Silkworm}

A standard strain P22 maintained at the Institute of Silkworm Genetics in Kyushu University was used. Animals at $72 \mathrm{hr}$ (day 3) and $148 \mathrm{hr}$ (day 7) after the 4 th molt were taken as gluttonous and mature larvae, respectively.

\section{Preparation of midgut cell nuclei}

The midgut was dissected out in physiological saline, and the trachea and Malpighian tubules attached to the organ were carefully removed and discarded. Nuclei were isolated essentially according to Chauveau et al. (1956) and Berendes and Boyd (1969) with slight modifications. Several midguts were homogenized in 3 volumes per weight of $2.3 \mathrm{M}$ sucrose solution containing 10 $\mathrm{mM} \mathrm{MgCl}_{2}, 3 \mathrm{mM} \mathrm{CaCl} \mathrm{Can}_{2}$ and $0.01 \mathrm{M}$ Tris- $\mathrm{HCl}$ buffer ( $\mathrm{pH} 7.8$ ) with 3 strokes of a Teflon-glass homogenizer. The homogenate was diluted 2 -fold with the buffered sucrose, and then filtered through 4 layers of nylon mesh. The filtrate was again mixed with the buffered sucrose to attain 20 volumes per weight of the starting material, and centrifuged at $60,000 \times \mathrm{g}$ for $45 \mathrm{~min}$ in a Beckman 30 rotor. The pellet was resuspended in $0.34 \mathrm{M}$ sucrose plus $10 \mathrm{mM}$ $\mathrm{MgCl}_{2}, 3 \mathrm{mM} \mathrm{CaCl}_{2}$ and $0.01 \mathrm{M}$ Tris-HCl buffer ( $\mathrm{pH}$ 7.8), and centrifuged at 250 $\mathrm{xg}$ for $10 \mathrm{~min}$. The pellet containing crude nuclei was washed twice with $0.01 \mathrm{M}$ Tris- $\mathrm{HCl}\left(\mathrm{pH}\right.$ 7. 8), $2 \mathrm{mM} \mathrm{MgCl}_{2}$ and $6 \mathrm{mM}$ mercaptoethanol, and the final pellet of purified nuclei was suspended in the same buffer. All the procedures were performed at $0-4^{\circ} \mathrm{C}$.

\section{RNA synthesis in vitro}

RNA was synthesized in a standard incubation mixture $(1 \mathrm{ml})$ containing $0.01 \mathrm{M}$ Tris $-\mathrm{HCl}(\mathrm{pH} 7.8), 2 \mathrm{mM} \mathrm{MgCl}_{2}, 6 \mathrm{mM}$ mercaptoethanol, $5 \mu \mathrm{Ci}{ }^{3} \mathrm{H}-\mathrm{ATP}$ $(60 \mathrm{Ci} / \mathrm{mmol}$, New England Nuclear Corp., Boston), $1 \mu \mathrm{M}$ each of GTP, CTP, UTP, $50 \mu \mathrm{M}$ phosphoenolpyruvate (Sigma Chem. Co., Saint Louis), $10 \mu \mathrm{g}$ phosphoenolpyruvate kinase (as above), $210 \mu \mathrm{g}$ bentonite purified according to Fraenkel-Conrat et al. (1961), 60 units penicillin, $1 \mathrm{mg}$ streptomycin, and nuclei. In order to determine the effects of hormone on RNA synthesis in vitro, $10 \mu \mathrm{g} /$ $\mathrm{ml}$ of ecdysterone (Rhoto Pharmaceutical Co., Osaka) was added to the standard incubation mixture. The mixture was incubated at $37^{\circ} \mathrm{C}$ for $60 \mathrm{~min}$.

\section{Isolation of RNA}

Crude RNA fraction was separated from the incubated nuclei together with the medium according to Schmidt and Thannhauser (1945), and Schneider (1945). Alternatively, total nucleic acids were extracted by means of a phenol method. An equal volume of $0.1 \mathrm{M}$ Tris- $\mathrm{HCl}$ buffer $(\mathrm{pH} 7.8$ ) plus $0.5 \%$ sodium dodecyl sulfate was added to the nuclei plus medium, and homogenized in a glass homogenizer. The homogenate was shaken with an equal volume of phenol saturated with the above buffer for $30 \mathrm{~min}$ at room temperature. After centrifugation for $10 \mathrm{~min}$ at $16,000 \times \mathrm{g}$ the phenol phase was discarded, and the water phase and interphase were reextracted with an equal volume of phenol as above. Nucleic acids were precipitated from the final water layer 
with ethanol, washed with ethanol, and stored at $-20^{\circ} \mathrm{C}$. Sometimes, nucleic acids were directly extracted from isolated midgut cell nuclei without any incubation. In a preliminary experiment, the purified nucleic acid preparation was treated with RNase-free DNase (Worthington Biochem. Corp., Freehold), but this resulted in some degradation of RNA as analyzed by means of polyacrylamide gel electrophoresis described below. Therefore, DNA was not eliminated from the samples. Contaminating DNA did not interfere with RNA analysis since DNA moves more slowly than RNA in gels (see Fig. 2) and little radioactivity was detected in the DNA region of gels (see Fig. 4).

Gel electrophoresis of RNA

RNA was electrophoresed on $2.4 \%$ acrylamide gel according to Bishop et al. (1967). The gels were scanned at $260 \mathrm{~nm}$ by a Gilford Model 2400 spectrophotometer and sliced into 4-mm fractions. Each slice was placed in a vial and dissolved with $\mathrm{H}_{2} \mathrm{O}_{2}$ at $60^{\circ} \mathrm{C}$. Radioactivity was determined in a toluenebased scintillator with a Beckman Model LS-250 scintillation spectrophotometer.

\section{RESULTS}

Isolated nuclei from midgut

Midgut cell nuclei from the larvae at the gluttonous stage (day 3 of the 5th instar) are shown in Fig. 1. The nuclei had no cytoplasmic contamination

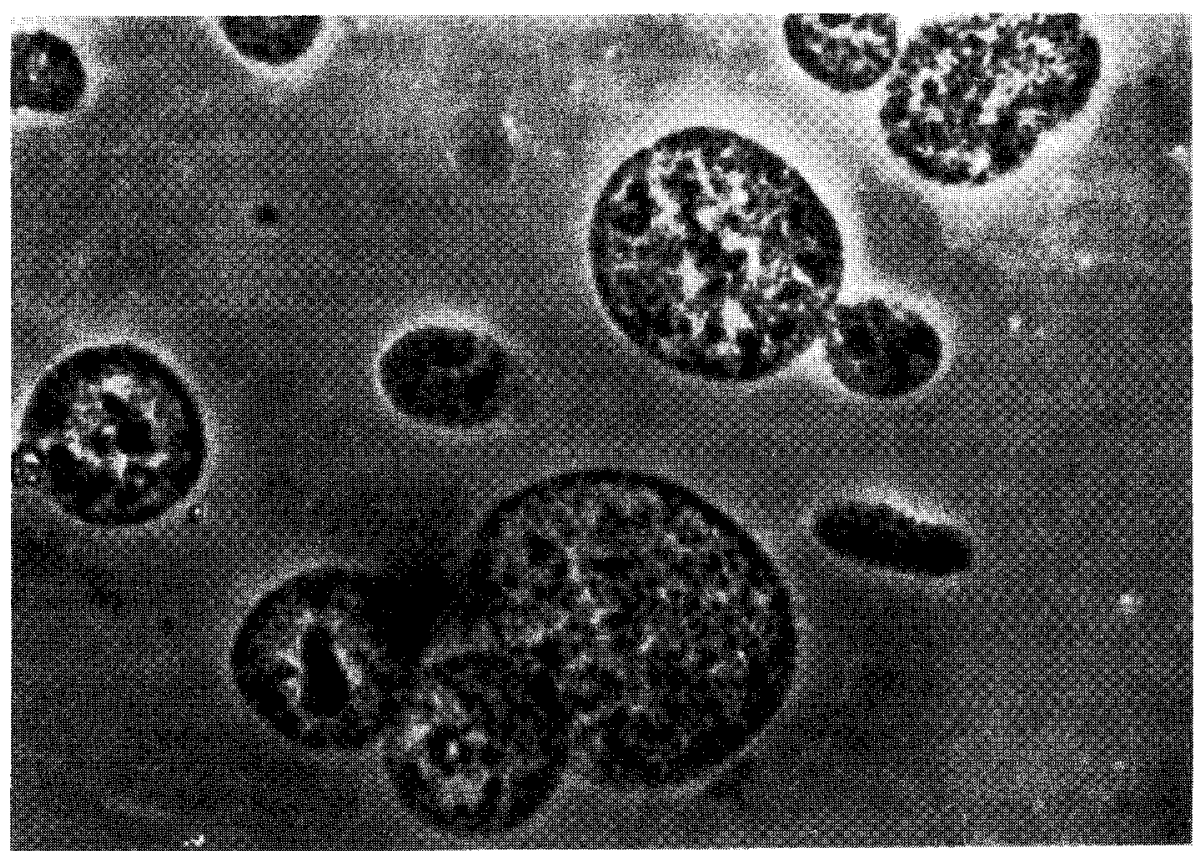

Fig. 1. Purified midgut cell nuclei of larvae at day 3 of the 5 th instar (x360). Nuclei were suspended in a buffered $0.34 \mathrm{M}$ sucrose solution as described in Methods. 


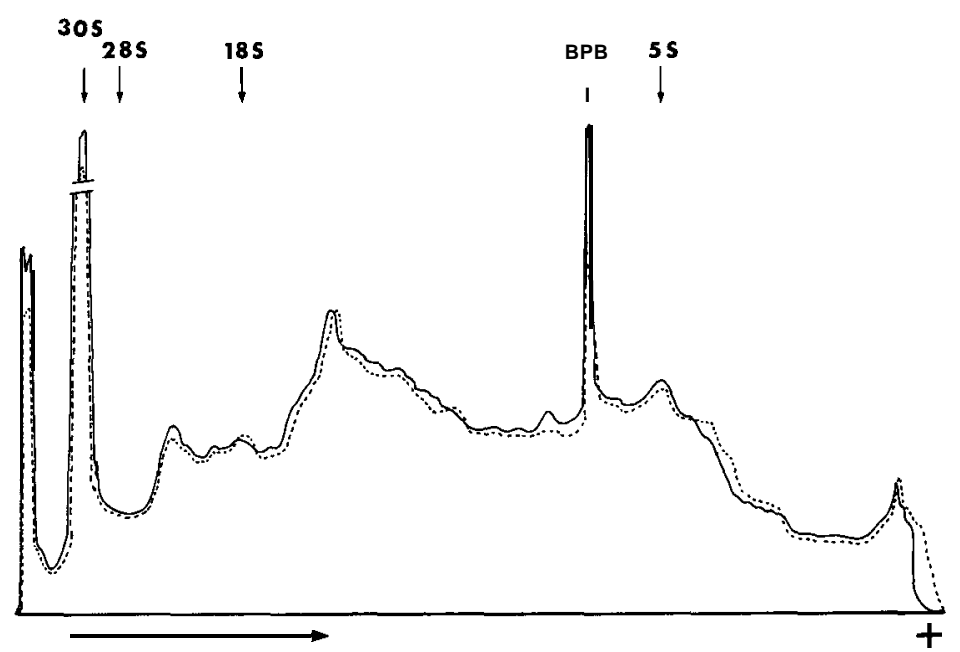

Fig. 2. Polyacrylamide gel electrophoresis of nucleic acids extracted with phenol from isolated midgut cell nuclei. Nucleic acids were allowed to migrate through a $2.4 \%$ gel column and the gel was scanned at $260 \mathrm{~nm}$. Both of RNA's from larvae at day 3 (solid line) and day 7 (hroken line) showed almost the same patterns. The first peak was identified to be DNA as it persisted after RNase- or alkali-treatment. $S$ values indicated were calculated from a calibration curve made with rat liver RNA electrophoresed in parallel. BPB, bromophenol blue.

apparently. Three different sizes of nuclei were seen; this heterogeneity may not be due to artifact, since the nuclei were surrounded by a definite nuclear membrane, and the form of nuclei at this stage is relatively stable against the changes of environmental conditions (unpublished observations). Possibly, the large, middle and small nuclei may be originated from the columnar, goblet and generative cells, respectively. This inference comes from a previously published morphological observation of midgut cells (Tsujita, 1943). On the other hand, the nuclei from the mature larvae were fragile, and uniform in shape (unpublished observations). This is in agreement with the morphological observation that the midgut cells at this stage are degenerating, and dimensional difference among the cells becomes indistinguishable (Tsujita, 1943).

Classes of nuclear RNA and its stability during incubation

RNA was extracted from the isolated nuclei without any incubation, and analyzed by means of polyacrylamide gel electrophoresis. As shown in Fig. 2, many groups of RNA were found to exist in the nuclei. No difference was detected between nuclear RNA's from midgut nuclei of the gluttonous and mature larvae (Fig. 2); thus the nuclei of both stages seemed to contain almost the same types of RNA. Furthermore, RNA was also extracted from the nuclei incubated as described in Methods (but in this case ${ }^{3} \mathrm{H}$-ATP was replaced by cold ATP) and gel electrophoresed as above (figure not shown). Similar patterns were obtained irrespective of whether nuclei were incubated or not, and it was concluded that RNA degradation may not happen during the incubation. 


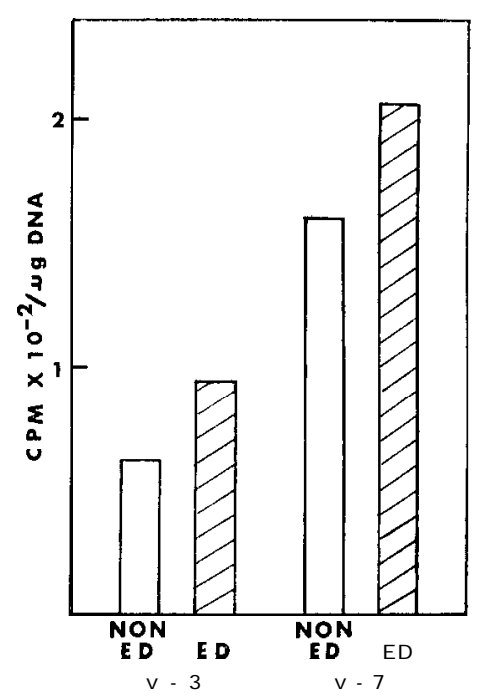

Fig. 3. RNA synthesis in cell nuclei isolated from the midgut of larvae at day $3(\mathrm{~V} 3)$ and day $7(\mathrm{~V}-7)$ of the 5 th instar. The nuclei were incubated for $60 \mathrm{~min}$ with ${ }^{3} \mathrm{H}-\mathrm{ATP}$, and the crude RNA fraction was isolated by means of the Schmidt-Thannhauser-Schneider method. "NON ED" indicates RNA synthesized without ecdysterone, and "ED" with rcdysterone. The pattern was essentially reproducible in 4 separate series of cxperiments, and a typical result is illustrated. The paired t-test was made with the results for the hormonal stimulation assuming that the restrictions for the test could hold in this case. The differences for $\mathrm{V}-3$ and $\mathrm{V}-7$ were significant at a level of 0.01 and 0.025 , respectively.

Developmental changes and hormonal stimulation in rate of RNA synthesis

The rate of bulk RNA synthesis was studied by incubating isolated nuclei with ${ }^{3} \mathrm{H}$-ATP for $60 \mathrm{~min}$ invitro as described in Methods. RNA fraction separated according to Schmidt and Thannhauser (1945), and Schneider (1945) was directly assayed for radioactivity. The results are shown in Fig. 3. With respect to the mature larvae (day 7), the rate was 2.5 times as large as that for the gluttonous larvae (day 3). The absolute rates of synthesis based upon measurements of specific activities of the precursor pools were not evaluated. Neverthless, it is significant that adding ecdysterone to the incubation mixture caused an increase in incorporation into the nuclear RNA of both gluttonous and mature larvae (Fig. 3).

Newly synthesized RNA

RNA was extracted with phenol as described in Methods. The species of RNA newly synthesized (i. e. labeled for $60 \mathrm{~min}$ ) were compared between the gluttonous (day 3) and maturation stage (day 7) by assaying radioactivity in polyacrylamide gels as described in Methods. Figures $4 \mathrm{~A}$ and $\mathrm{C}$ indicate that, although many fractions were common to both stages, $16 \mathrm{~S}, 10 \mathrm{~S}$, and especially $4 \mathrm{~S}$ RNA's were peculiar to the maturation stage. In contrast, RNA's specific to the gluttonous larvae seemed to be very scarce. 


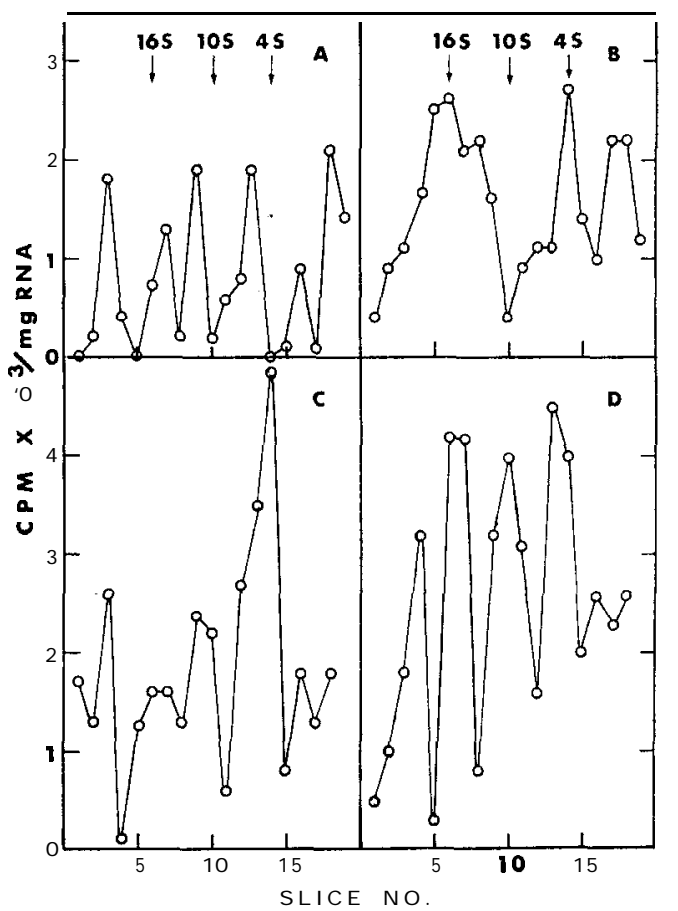

Fig. 4. Polyacrylamide gel electrophoresis of nucleic acids newly synthesized in isolated midgut cell nuclei. The nuclei were incubated for $60 \mathrm{~min}$ with ${ }^{3} \mathrm{H}-\mathrm{ATP}$, and nucleic acids were electrophoresed as described in the legend to Fig. 2. Radioactivities in 4-mm gel slices were counted. A, day-3 midgut cell nuclei incubated without ecdysterone; $B$, as $A$ but incubated with ecdysterone ; $\mathrm{C}$, day-7 midgut cell nuclei incubated without ecdysterone; D, as C but incubated with eccysterone. Slice no. 1 corresponds to DNA peak but no significant counts were detected here. The RNA species indicated by arrows were specific to day-7 nuclei or to hormone-treated nuclei. The patterns were reproducible in 3 separate series of experiments.

\section{Effects of ecdysterone on synthesis of RNA species}

The above difference in species of newly synthesized RNA between the two developmental stages may be related to hormonal control systems. In order to study this point, RNA's synthesized in vitro with or without ecdysterone added to the reaction mixture were compared. As shown in Figs. 4A and $\mathrm{B}$, qualitative changes were detected in case of the gluttonous stage (day $3)$; in the hormone-treated nuclei new species of RNA appeared, while some other species detected in the control were repressed to some extent. On the other hand, ecdysterone affected nuclei from the mature larvae rather quantitatively, stimulating the synthesis of RNA species which were also produced without ecdysterone (Figs. $4 \mathrm{C}$ and D). 


\section{DISCUSSION}

At the period of larval maturation, the midgut of Bombyx mori begins to degrade (Kawaguchi, 1931; Machida, 1933; Tsujita, 1943). At this stage the midgut no more functions as a digestive organ, but its activity for RNA synthesis was found to be higher compared to that of the actively feeding larvae (Fig. 3). Moreover, additional species of RNA were produced by midgut cell nuclei of the mature larvae (Figs. 4A and C). This phenomenon might be explained by assuming that some species of RNA are necessary for the degradation of larval midgut and the reformation of pupal midgut that follows. These changes may be switched by the molting hormone, ecdysone.

There is evidence that isolated cell nuclei are stimulated to synthesize RNA by exogenous steroid hormones (Congote et al., 1969), and it holds also for the present case. The results described above show that ecdysterone affected RNA synthesis in isolated midgut cell nuclei in the following $t w o$ modes; first, it caused an increase in amount of RNA's which are synthesized even without ecdysterone, as seen in the results for the maturation stage (Figs. 4C and D). The latter stage is the period when the endogenous titre of ecdysone is very high: it may be that in such cases exogenous hormone acts only in the quantitative phase. Second, the hormone induced synthesis of RNA's which are absent in a hormone-free control. This was the case for the young, gluttonous larvae (Figs. $4 \mathrm{~A}$ and $\mathrm{B}$ ), whose endogenous titre of ecdysone is very low. It is interesting to note that the ecdysterone-stimulated young cell nuclei gave RNA species simillar to those for the mature larvae (compare Figs. 4B and C). It is possible that the present incubation system with the exogenous hormone mimicked at least some of the events naturally occurring in metamorphosing tissue cell nuclei.

The above changes in RNA spectrum may not totally be the result of transcriptional change itself but can also be affected by some modulation in "processing" of initial transcripts. It is known that cell nuclei in general contain many kinds of RNA which are turning over very rapidly (e. g. Soeiro et al., 1966). In the present study, nuclei were labeled for a relatively long period of 60 min; under these conditions various processing intermediates may be revealed rather than the initial transcripts with high-molecular-weights. At any rate, details for the identification and physiological significance of the RNA species discussed in this paper remain to be investigated.

\section{ACKNOWLEDGEMENTS}

The authers express their thanks to Professor H. Chikushi and Dr. H. Doira for their invaluable advice, and to the members of the Institute of Silkworm Genetics in Kyushu University for their kind supply of silkworms. 


\section{REFERENCES}

Berendes, H. D. and J. B. Boyd 1969 Structural and functional properties of polytene nuclei isolated from salivary glands of Drosophila hydei.J. Cell Biol.. 41: 591-599

Bishop, D. H. L., J.R. Claybrook and S. Spiegelman 1967 Electrophoretic separation of viral nucleic acids on polyacrylamide gels. J. Mol. Biol., 26: 373-387

Chauveau, J., Y. Moule and C. Rouiller 1956 Isolation of pure and unaltered liver nuclei morphology and biochemical composition. Exptl. Cell Res., 11: 317-321

Congote. L. F.. C. E. Sekeris and P. Karlson 1969 On the mechanism of hormone action. XIII. Stimulating effects of ecdysone, juvenile hormone and ions on RNA synthesis in fat body cell nuclei from Calliphora erythrocephala isolated by a filtration technique. Exptl. Cell Res., 56: 338-346

Eguchi, M.. S. Furukawa and A. Iwamoto 1975 Role of the midgut, crop, and maxillae of Bombyx mori in the production of cocoon-digesting enzyme. J. Insect Physiol., $21: 1365$ 1372

Fraenkel-Conrat, H., B. Singer and A. Tsugita 1961 Purification of viral RNA by means of bentonite. Virology, 14: 54-58

Fujii, H. and B. Sakaguchi 1971 Effects of ecdysterone on RNA and protein synthesis in midgut of Bombyx mori. Proc. Sericult. Sci. Kyushu, No. 2: 72

Kawaguchi. E. 1931 Über den Dimorphsmus der Epithelzellen im Mitteldarm der Seidenraupe (Bombyx mori L.) J. Dept. Agric. Kyushu Univ., 3: 47-64

Machida,J. 1933 On the epithelium of the mid-gut in the silkworm larva. Bull. Seric. Exp. Sta. Tokyo, 11: 211-293

Schmidt, G. and S. J. Thannhauser 1945 A method for the determination of desoxyribonucleic acid, ribonucleic acid, and phosphoproteins in animal tissues. J.Biol. Chem., 161: 83-89

Schneider, W. C. 1945 Phosphorous compounds in animal tissues. 1. Extraction and estimation of desoxypentose nucleic acid and of pentose nucleic acid. J.Biol.Chem., $161: 293$ 303

Soeiro, R.. H. C. Birnboim and J. E. Darnell 1966 Rapidly labeled HeLacell nuclear RNA. II. Base composition and cellular localization of a heterogeneous RNA fraction. J. Mol. Biol., 19: 362-372

Tsujita, M. 1943 Histological and cytological studies of the midgut epithelialcell in the silkworm. Bull.Seric.Exp. Sta. Tokyo, 11: 211-293 